\title{
THE CONDITION OF WORKING WOMEN, FROM THE WORKING WOMAN'S VIEWPOINT
}

\author{
By Rose H. Phelps Stokes, \\ New York City.
}

The topic, "The Condition of the Working Woman," itself suggests forcibly the chief evil which working women have to face. The selection of this particular topic by those who have arranged the program of the annual meeting of the Academy calls attention to the assumption prevailing throughout our country, particularly among men and women of the employing class, that a rather natural distinction exists between women who work and women who do not. It is not uncommon to find the view held by people of culture that it is entirely proper for women to be thus divided: for some to produce far more than they require to supply the needs of themselves and their families, and for others to consume far more than their own efforts produce.

Obviously it would be improper to regard the products of manual toil as the only products necessary to human welfare. It is evident that grace and culture and refinement are in themselves human products of much usefulness, and that a world devoid of these would be a cold and dreary place in which to pass our days. Grace and culture and refinement, where these are expressions of real feeling and of depth of human desire to be just and courteous and true, are evidently of large human value; so much so, that where economic and industrial conditions prevail such as to hinder or prevent their development, it becomes desirable to ask whether the conditions are necessary which thus thwart progress, and whether they could not be so modified and changed by human effort that none need be deprived of opportunity to make constant progress toward all that is admirable in manhood or womanhood.

It must be perceived by even the casual observer that working women, as a rule, are permitted to retain but a portion of the value of what they produce; that they add more value to the material upon which they work than they receive in payment for their labor; 
that the average working woman produces, on the whole, more than she consumes, and that the excess is consumed by those who produce insufficient for their own maintenance, and who would probably resent being called working women; yet who are thus as dependent as any pauper is upon the labor of others. In other words, much of the hardship of the working classes is consequent upon the fact that they are obliged not merely to support their own families, but to contribute, whether they will or not, to the support of other families which live in idle luxury upon the products of working people's toil. It is the nearly universal recognition of this fact among the working people of our country that leads more than all else to strikes and industrial disturbances, to ill-will, to class hatred, and to that craving for larger justice which underlies the socialistic program.

The working woman sees herself and her factory sisters working under conditions detrimental to the growth of body, mind and spirit. Ten to fifteen hours a day spent in the monotonous repetition of purely mechanical actions, amid ill-ventilated and otherwise unsanitary surroundings, destroys bodily vigor or prevents its development. Those inherent tendencies to spontaneous and glad thought and action which are essential to the development of a higher type of personality become paralyzed. The working woman sees, or at least feels, that excessive toil on her part would be unnecessary if the burdens of production were more fairly distributed, and if waste prevailed less widely. She sees no justice in an economic system which requires of one woman physical and spiritual exhaustion, in order that some other woman, absolved from the necessity of labor through the accident of birth or otherwise, may waste in idleness and luxury her product and the product of her fellows.

The average working woman knows from her own experience, and from that of the workers about her, that under the existing economic system she must ever live at the margin of subsistence, and that through no effort of her own can she rise to a condition of rightful and necessary independence, where daily fears and anxieties would give place to opportunities for bodily and spiritual rest and recreation and health. Moreover, she sees that, situated as she is, driven by hard necessity, she must pass through a long period of her life deprived of opportunities for those social relations with (628) 
her fellows that are essential to the development of much that is best and noblest in her nature. In proportion as she lives and labors as a mere machine the progress and growth of her soul is apt to be thwarted and checked. Not only is she commonly ignorant and of narrow vision, but she is denied, most often, opportunity for physical or mental or spiritual development.

On every hand evidence is accumulating showing the havoc wrought upon the physical health of the workers by the harmful environmental conditions amid which their work is done. The inroads made by pulmonary affections upon women who labor in the spinning, weaving and felting industries are appalling. Results are similar wherever labor is required for excessive hours under unhygienic conditions. Women who bend over the sewing machine for ten to fifteen hours a day, or over artificial flower benches or over cigar benches in the health-destroying atmosphere of tobacco dust, in ill-ventilated, ill-lighted shops, or in the dingy atmosphere of a tenement room, readily fall prey to germs of disease in the air and food and drink.

Nearly all of those diseases which so devastate our communities owe their inception to the impaired power of resistance of the individual attacked. We all breathe daily the germs of infectious disease. The secretion of our mouths is found to teem with germs of putrefaction and decay, and very often with those of malignant and infectious disease. The germs of typhoid fever and dysentery are common in the waters we drink. Pathologists tell us that characteristic lesions of tuberculosis and appendicitis are found in most cadavers when subjected to searching post-mortem examinations, whatever may have been the cause of death. In other words, all become invaded with the germs of disease, but, roughly speaking, those alone succumb whose power of resistance is low. The working woman knows the lassitude and depression and weakness which prevailing industrial conditions entail, and she can see no justice in an industrial system which maintains and perpetuates conditions inimical to health and to character.

For bodily health is not all that is destroyed or impoverished. Character, too, often suffers as well. Excessive hours of toil and consequent craving for relaxation and refreshment lead naturally to the seeking of gayety and recreation after the day's work is done; and conditions under which alone gayety and recreation can be had (629) 
by the average working girl in our large cities are far from conducive to the highest standards of social life.

Every working man and working woman feels the need of recreation and social enjoyment, and particularly so after hours of arduous toil. It is but natural for people, young people especially, to seek recreation and refreshment in social pleasures of one kind or another. Now, it must be borne in mind that in many of our industrial communities in the crowded sections of our cities opportunities for wholesome enjoyment are few and far between. Where opportunities for wholesome recreation and enjoyment cannot be found, unwholesome enjoyment and recreation will be had. It is futile to speak against the evils of cheap dance halls and vulgar resorts so long as opportunities for a wholesome social life are not in existence.

It is true that many employers of women's labor seek to supply the need to which I have alluded by the introduction into their industrial communities of what has become known as welfare work. Welfare secretaries are employed to promote the social and recreative interest of working women, and comfortable reading rooms, rest rooms, social rooms, game rooms, dining rooms, and other facilities are provided, and attempt is made to improve the conditions of life and labor in the factory and in its immediate environs; and the working girl is expected to duly appreciate these advantages, and to look upon the employer who provides them as a true friend of her class.

The working girl may indeed look upon such an employer as "friendly" to her class, but friendship in this narrow sense does not seem to her to fulfill the requirements of justice. What the working girl wants (like the working man) is fair hours of labor and fair pay for its product. Unless she feels that she is receiving in payment for the product of her toil a fair portion of the value of that product, she cannot easily regard those as her friends who withhold from her the portion, however small, of that which is her due. Welfare work under such circumstances she regards as but a pacifying measure to secure her good will despite injustice or wrong, or reads into the motive of the employer the desire to improve his business by appearing before the patrons of that business as a "fair" employer.

Far be it from the working girl to object to improvement of (630) 
industrial conditions, however inadequate such improvement may be. But, while appreciating the improvement, she knows that even with it she must necessarily get less than the fair reward for her labor if she receive for her day's work barely enough to hold body and soul together, while those who exploit her labor live in luxury and wastefulness, and spend in extravagant living what she has earned. She often realizes that the idle classes harm not only the working classes by their extravagances, but themselves as well. She sees in a vague sort of way that they who do wrong to others wrong themselves as well, because they make themselves unjust, and she can see neither rhyme nor reason in an economic system that checks tendencies toward spiritual perfection-the goal and reason of all human life.

An enormous majority of working women live and labor under conditions inimical to health and happiness. Nearly one-third of the deaths among working women between the ages of twenty and forty-five occur from tuberculosis alone, and these deaths are due almost always to needlessly bad conditions of tenements and shops. The bad conditions are maintained, usually, by people of the employing and propertied classes, who prefer to continue them rather than suffer such slight curtailment of revenue as improvement might cause.

In one block of New York City there has been a new case of tuberculosis reported to the Board of Health once every twelve days, as an average, for the past nine years, and from six houses on that block one new case has been reported every thirty-two days. In one flat in one of those houses four families successively were devastated by that disease in five years; yet, whenever attempt is made by the Board of Health or by other bodies of public-spirited citizens, to secure such alterations in that block as would eliminate its death-dealing features and replace them with health-giving ones, the cry is raised of interference with vested rights, of interference with contract between landlord and tenant, and of interference with the right of every individual to conduct himself as he pleases in relations which are his own. As a result, all attempts at bettering the area have failed, and year by year scores of additional victims become impregnated with the conditions and fall easy prey to the disease. Similarly throughout the factories and workshops of our land, unsanitary conditions and starvation wages each year weaken 
and kill scores of thousands of victims. The destruction is as needless in one case as in the other.

A few weeks ago it was shown before the Assembly's Committee on Labor and Industries, at Albany, that in one widely prevailing trade (a man's trade, that of metal polishing) 92 per cent. of all the workers die of tuberculosis or other pulmonary disease, and that 82 per cent. of them die before reaching the age of forty years. Yet a vigorous effort was made by representatives of the employing class in that industry to repeal the mandatory provisions of the law which requires the use of exhaust fans or blowers wherever harmful dust is produced in the workshops and factories of New York State. Even with the wide use of the blowers and fans, the appalling mortality prevails. Without fans or blowers to remove the deleterious dust from the air, the vital statistics of the industry would be more terrible still. With blowers the costs of production in the industry are enhanced by the cost of the blowers. Without blowers the cost of production would be enhanced to an immeasurably more terrible degree by the cost of still more human lives sacrificed in a mad scramble for wealth.

Throughout the length and breadth of our land the terrible question faces our people: Shall the health and lives of our workers continue to be jeopardized and sacrificed to swell the incomes of the few?

The working girl does not object to the accumulation of wealth when accumulation harms no one; but her soul cries out in revolt against the callousness and heedlessness of those who in their mad greed for gain ignore the conditions under which the gain is produced. She sees herself and her sisters struggling ten or twelve or fourteen hours a day under conditions destructive to health and to progress, in order that the incomes of employers and their families may be large enough to sustain them in luxurious living. She and her working sisters see the daughters of their employers lead idle and self-indulgent lives upon profits wrung from the health and strength, and often from the virtue of those who must ignore industrial injustice or starve. "By what right," she cries, "whether divine or human, am I and my sisters compelled to exhaust body and soul that other human beings may be idle and wasteful, and even destroy their own souls in vicious and thoughtless living?"

The working woman sees the women of the employing class 
mock the teachings of their great religious leader by manifesting everywhere, contrary to His injunctions, pride, vain glory, and hypocrisy. Instead of "remembering the Sabbath day to keep it holy" they choose that day of all others to "make broad their phylacteries and enlarge the borders of their garments," and to ignore His injunctions to humility and consideration of one's fellows.

"Love thy neighbor as thyself" sounds hollow and derisive to the working girl, who on the Sabbath day, and many other days, sees wealth and fashion "pass by on the other side" in all their show and glitter, while the victims of greed and oppression lie sick and poverty stricken in tenements close by.

As to the subject of religion, it is difficult for the working girl to rely upon its teachings, when on every hand she sees the wicked, the dishonorable and the covetous in high places, and the majority of honest workers abased, and compelled by circumstances beyond their control to toil and suffer excessively; particularly is it difficult for her to respect those churches in which "uppermost seats" are bought and paid for, like so much merchandise, with money unjustly earned. The working girl who received her first Christian precepts from a hard-working mother may have a deep and abiding respect and love for Jesus and His teachings, and faith in the ultimate triumph of right, but she cannot respect that false religion miscalied Christianity, and those false teachings of its preachers, which confine themselves to blasphemously singing praises of God while repudiating the great commandment to "Love thy neighbor as thyself." For there is no loving one's neighbor as one's self, says the working women, where one's self lives in wealth and luxury and affluence while one's neighbor, like the victim in the parable, lies robbed, wounded, starved and dying on the Jericho road, priests, churchmen and pharisees seeing his affliction, but "passing by on the other side."

Contributions made in aid of rescue homes, missions, settlements, welfare work and other "charities," representing a few dollars spared by employers from incomes wrung from human lives, are commonly regarded with distrust, and often as less commendable than the gift of Ananias and Sapphira; but those people who personally devote themselves to the work are held in high esteem, 
and frequently warmest friendships are formed between them and the working women.

Many troubles are caused to the less serious minded working girls through natural, though foolish, attempts to imitate the habits and dress of those who live and dress extravagantly. Earnings needed for bodily sustenance and protection are wasted upon ribbons and feathers and modish dresses, for no other reason than that they believe such expenditures raise them to a higher social level than they could otherwise attain. Money needed for the relief and aid of a sick neighbor, or for food or clothing for a younger brother or sister, is often squandered on imitation jewels or other finery, where no other motive exists than that of vanity and vain glory, prompted by the extravagance and ostentation of the rich.

It is, of course, thought by wealthy men and women that no blame is theirs if others follow, foolishly, foolish and wasteful examples. The attitude of the wealthy differs greatly in this regard from that of St. Paul, who in his first letter to the Corinthians said, "Take heed lest by any means this liberty of yours become a stumbling block to them that are weak." Unfortunately, there is not a very large percentage of women in any class who realize fully that the more worth a woman has in herself the less worth is she apt to put on herself, and that we are held in esteem a great deal more for what we have in us than for what we have on us. Efforts at show and adornment, copied from the rich, lead often to bitterest and narrowest heart yearnings and jealousies and despair, and money and time and thought and effort which could be expended far more profitably in promoting real human interests or in supplying real human needs are wasted and squandered in finery and folly. This condition of affairs cannot easily be changed, unless those women who pose as the working girls' superiors will set a superior example.

"How these working girls do dress! No wonder they are poor!" exclaimed a very well meaning and overdressed woman whom I met downtown one day, a woman who did not know me and whom I did not know. "Look at their hats and suits!" The woman expected tatters, and was rather surprised and shocked to find decent clothing, perhaps a trifle gay. "Why the children uptown dress no better than that!" I was glad for the working girls that their critic took no walk through the East Side streets, and thereby 
avoided setting further harmful examples of extravagance, show and vanity, already so widely set by her class.

A word must be said in regard to the working girl's attitude toward that patronizing, condescending type of interest shown so often by rich women toward working girls' clubs. It is far too common in our settlement houses and elsewhere, even in tenement homes themselves, to find wealthy women very expensively dressed attempting to encourage the so-called unfortunates by visiting them and telling them what they should do. Not long ago, in one of the principal settlement houses of New York, a very fashionably dressed woman, a lorgnette dangling from her finger tips, opened the door of a working girls' club, uninvited, and, raising her lorgnette to her eyes, surveyed the group before her, and, as though desiring to compliment the girls, remarked in the hearing of all, "What a very attractive looking lot of working girls these are!" This sort of thing is by no means rare. Wealthy women visiting settlement houses, as they do in large numbers, feel offended if their desire to visit intrusively every club in the building is discouraged by those in charge. In some of the larger settlement houses an evening rarely passes without from two to one-half dozen groups of such visitors showing their lack of regard for the feelings of others by intruding upon the privacy of one club after another, inspecting them successively as they inspect animals in their cages at the zoo. As a rule the poorer girls, members of these clubs, have sufficient good breeding to refrain from manifesting resentment at the intrusion, but too often such intrusion on the part of merely curious persons, slumming parties, and so forth, are carried to the degree of extreme discourtesy and become intolerable. But good-will and pleasure are always manifested by the members when they are visited out of pure friendliness, without condescension and without patronage.

And now a word as to the attitude of the working girl toward organized charity. She knows that there is no true charity except where there is true sympathy, and that true sympathy can exist only in proportion as there is true understanding of personal needs and feelings. To be sure, there are many working women who will readily accept donations of money or food or clothing, whether the gifts be given by ward politicians seeking the votes of the husbands, or by such of the rich as seek through "charity" to "cover a multitude of sins," or by societies which advertise conspicuously the 
donors to their funds; but most self-respecting women would rather go without asking for aid of any kind until they are half starved and half frozen than accept the doles of hard-hearted men in high places, or the doles of ostentation, hypocrisy, or sham, wherever or however offered.

Even where charitable societies seek in as kind a manner as they know how to provide relief for those genuinely in need, the methods which they sometimes pursue to ascertain the reality of the need are most harmful. Particularly harmful is the custom of such societies to spy upon applicants and to seek through secret questioning of neighbors to learn of every weakness or misdeed that might necessitate labelling the applicant as "unworthy," and then, after arousing the suspicion or ill-will of the neighbors, refusing to relieve. Even where, after such investigation, the applicant has been declared "worthy," and relief has been given, the poor woman henceforth is known to her neighbors as a dependent upon public charity, and at once falls in her own estimation, and in that of her neighbors as well, who usually compose all of her social acquaintances. Let those of some inagination endeavor to consider the position of such a woman and of her family.

This prevailing distinction that is so commonly made between "worthy" and "unworthy" applicants for relief is, in the opinion of the writer, most mistaken and unfortunate. Not that every drunkard and loafer should be maintained in vice and idleness by the gifts of well-meaning people, or that any one should be given anything inimical to his or her highest welfare, but no man or woman is so degraded as to be unworthy of aid to a better and worthier life. The more degraded men and women are the more worthy they are of aid to nobler living and of relief from the thralldom of evil ways and evil environments. We cannot have too much of the kind of relief that does truly relieve, or too much aid of the kind that does enable men and women to become more self-respecting, self-sustaining, self-denying members of a community. There is no relief in throwing an anchor to a drowning man or in throwing money to one who is being morally and spiritually drowned in vice and profligacy. What the struggler needs in either instance is an opportunity to live and labor under conditions less destructive of physical or moral welfare. The relief must be suited to the sufferer, but relief of the right kind need never be withheld. 
More fellow-feeling is what the world most needs, more true sympathy, more determination to promote justice and right living, by being just and living right one's self; more readiness to subordinate one's personal desires in consideration of the needs of one's fellows, and of the underlying causes which occasion those needs; more of the sort of charity which leads the individual not merely to offer aid to those who suffer, but to search out and remove from human environments the needlessly harmful conditions and the farreaching manifestations of human greed and injustice that usually underlie the conditions to which, in last analysis, most of the suffering is due. 